\title{
Rubellimicrobium mesophilum sp. nov., a mesophilic, pigmented bacterium isolated from soil
}

Correspondence

Chang-Jin Kim

changjin@kribb.re.kr

\author{
Syed G. Dastager, Jae-Chan Lee, Yoon-Jung Ju, Dong-Jin Park \\ and Chang-Jin Kim
}

Functional Metabolomics Research Center, KRIBB, Daejeon 305-806, Republic of Korea

\begin{abstract}
A pink- to light-reddish-pigmented, aerobic, pointed, budding, mesophilic strain designated MSL- $20^{\top}$ was isolated from soil from Bigeum island, Korea. The isolate was Gram-negative. Cells were motile rods without flagella. The temperature and $\mathrm{pH}$ for growth were $20-37^{\circ} \mathrm{C}$ (optimum $28^{\circ} \mathrm{C}$ ) and $\mathrm{pH}$ 7.0-11.0 (optimum pH 7.0 \pm 0.2 ). Q-10 was the predominant respiratory ubiquinone. The major fatty acids were $\mathrm{C}_{16: 0}(37 \%), \mathrm{C}_{18: 1} \omega 7 \mathrm{c}(36 \%)$ and 11 -methyl $\mathrm{C}_{18: 1} \omega 7 \mathrm{c}$ $(12 \%)$. Phylogenetic analysis based on the $16 \mathrm{~S}$ rRNA gene sequence revealed that Rubellimicrobium thermophilum DSM $16684^{\top}$ was its closest neighbour ( $95.2 \%$ similarity); the isolate had less than $97.0 \%$ similarity to all species with validly published names.

Chemotaxonomic data were determined for this isolate, including peptidoglycan type, diagnostic sugar composition, fatty acid profiles, ubiquinones and polar lipids; the results supported the affiliation of strain MSL- $20^{\top}$ to the genus Rubellimicrobium. The DNA G+C content was $72.3 \mathrm{~mol} \%$. On the basis of the phenotypic, chemotaxonomic and phylogenetic data, strain MSL- $20^{\top}$ represents a novel species of the genus Rubellimicrobium, for which the name Rubellimicrobium mesophilum sp. nov. is proposed. The type strain is MSL-20 ${ }^{\top}\left(=\mathrm{KCTC} 22012^{\top}\right.$ $=$ DSM $19309^{\top}$ ).
\end{abstract}

The genus Rubellimicrobium was proposed by Denner et al. (2006) for a reddish-coloured, Gram-negative, rodshaped bacterium that is phylogenetically considered to be a member of the order Rhodobacterales of the class Alphaproteobacteria. Members of this order are phenotypically, metabolically and ecologically diverse (Garrity et al., 2005) and include photoheterotrophs that can also grow photoautotrophically or chemotrophically under appropriate environmental conditions. The genus Rubellimicrobium contains only one species, Rubellimicrobium thermophilum (Denner et al., 2006), isolated from coloured slime deposits on paper machines. In this paper, we report a mesophilic species of Rubellimicrobium isolated from soil from Bigeum island, Korea.

During a study of the microbial flora of Bigeum island, a red-pigmented strain, $\mathrm{MSL}-20^{\mathrm{T}}$, was isolated and identified from a sediment soil sample. Further study of strain MSL- $20^{\mathrm{T}}$ based on a polyphasic approach including morphological observation and physiological and chemotaxonomic analysis showed that this isolate represents a novel species of the genus Rubellimicrobium.

Strain MSL-20 ${ }^{\mathrm{T}}$ was isolated on 10-fold-diluted R2A medium at $28{ }^{\circ} \mathrm{C}$ and maintained routinely on the same

The GenBank/EMBL/DDBJ accession number for the 16S rRNA gene sequence of strain MSL-20 ${ }^{\top}$ is EF547368. medium and as a glycerol suspension $\left(20 \%\right.$, v/v) at $-70{ }^{\circ} \mathrm{C}$. Biomass for chemical and molecular systematic studies was obtained by cultivation at $28{ }^{\circ} \mathrm{C}$ for 1 week in flasks of R2A broth (Difco) ( $\mathrm{pH} \mathrm{7.0).} \mathrm{Cultural} \mathrm{characteristics} \mathrm{were}$ determined after 7 days at $28{ }^{\circ} \mathrm{C}$ by methods used in the International Streptomyces Project (ISP) (Shirling \& Gottlieb, 1966). Morphological properties, spores and mycelia were examined by light microscopy (Nikon; HFX-DX) and scanning electron microscopy with JEOL model apparatus Philips SEM 515 (Fig. 1). Morphological observation of $48-72 \mathrm{~h}$ cultures of strain MSL- $20^{\mathrm{T}}$ grown on diluted $\mathrm{R} 2 \mathrm{~A}$ medium revealed that the cells were motile, short rods, $0.4-0.7 \times 1.6-3.4 \mu \mathrm{m}$. The strain was examined for a range of phenotypic properties using standard procedures (Goodfellow, 1971; Williams et al., 1983). Utilization of sole carbon and nitrogen sources was investigated according to Tsukamura (1966). Tolerance to temperature $\left(10,20,28,37,45\right.$ and $\left.50{ }^{\circ} \mathrm{C}\right)$ and $\mathrm{NaCl}(0-$ $15 \%$, at intervals of $0.5 \%$ ) was tested using R2A as basal medium.

Phospholipid analysis was carried out as described by Lechevalier et al. (1981). Respiratory lipoquinone analysis was performed by HPLC according to the procedure of Altenburger et al. (1996). Biomass for quantitative fatty acid analysis was prepared by scraping growth from R2A plates that had been incubated for $4-5$ days at $28{ }^{\circ} \mathrm{C}$. The 


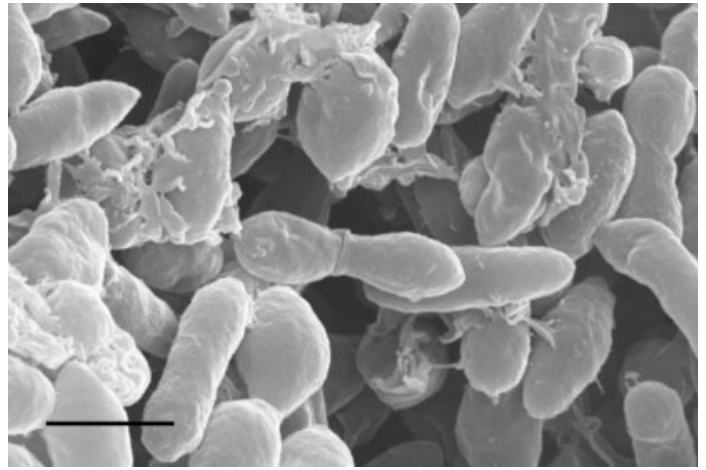

Fig. 1. Scanning electron micrograph showing monopolar cell growth of strain MSL- $20^{\top}$ incubated for 7 days on R2A medium at $28{ }^{\circ} \mathrm{C}$. Bar, $2 \mu \mathrm{m}$.

fatty acids were extracted, methylated and analysed using the standard MIDI Microbial ID system (Sasser, 1990; Kämpfer \& Kroppenstedt, 1996).

Extraction of genomic DNA and amplification of the $16 \mathrm{~S}$ rRNA gene were done as described by Rainey et al. (1996). An almost-complete 16S rRNA gene sequence of strain MSL- $20^{\mathrm{T}}$, comprising $1429 \mathrm{bp}$, was obtained and compared with sequences of type strains retrieved from the EzTaxon server (http://www.eztaxon.org/; Chun et al., 2007) and GenBank database. Phylogenetic analysis was performed using the software packages PHYLIP (Felsenstein, 1993) and MEGA version 2.1 (Kumar et al., 2001) after multiple alignment of the data using CLUSTAL_X (Thompson et al., 1997). Distances (using distance options according to the Kimura two-parameter model; Kimura, $1980,1983)$ were calculated and clustering was performed with the neighbour-joining method (Saitou \& Nei, 1987).
Bootstrap analysis (1000 resamplings) was used to evaluate the tree topology of the neighbour-joining data (Felsenstein, 1985).

Strain MSL- $20^{\mathrm{T}}$ contained ubiquinone Q-10 as the major quinone. Phospholipids detected were diphosphatidylglycerol, phosphatidylcholine and an unidentified aminolipid. The cellular fatty acid composition of strain MSL- $15^{\mathrm{T}}$ is given in the species description. 16S rRNA gene sequence similarities between strain MSL- $20^{\mathrm{T}}$ and type strains of species with validly published names were below $97.0 \%$. Phylogenetic analysis based on its complete 16S rRNA gene sequence showed that the novel isolate was most closely related to Rubellimicrobium thermophilum DSM $16684^{\mathrm{T}}$. A dendrogram (Fig. 2) confirmed that strain MSL- $20^{\mathrm{T}}$ and $R$. thermophilum DSM $16684^{\mathrm{T}}$ are phylogenetic neighbours, with $95.2 \%$ 16S rRNA gene sequence similarity and a bootstrap value of $99 \%$.

A comparison of the phenotypic properties of strain MSL$20^{\mathrm{T}}$ and $R$. thermophilum DSM $16684^{\mathrm{T}}$ revealed marginal differences, though they can be differentiated easily by their physiological properties, particularly their growth temperatures: $R$. thermophilum DSM $16684^{\mathrm{T}}$ is a thermophile (optimum growth at $45-54{ }^{\circ} \mathrm{C}$ ), whereas $\mathrm{MSL}-20^{\mathrm{T}}$ is mesophilic (growth at $20-37^{\circ} \mathrm{C}$ ) (Table 1).

In conclusion, the genotypic and phenotypic data show that strain MSL- $20^{\mathrm{T}}$ represents a novel species of the genus Rubellimicrobium, for which we propose the name Rubellimicrobium mesophilum sp. nov.

\section{Description of Rubellimicrobium mesophilum sp. nov.}

Rubellimicrobium mesophilum [me.so.phi'lum. Gr. adj. mesos middle; Gr. adj. philos loving; N.L. neut. adj. mesophilum middle (temperature)-loving, mesophilic].

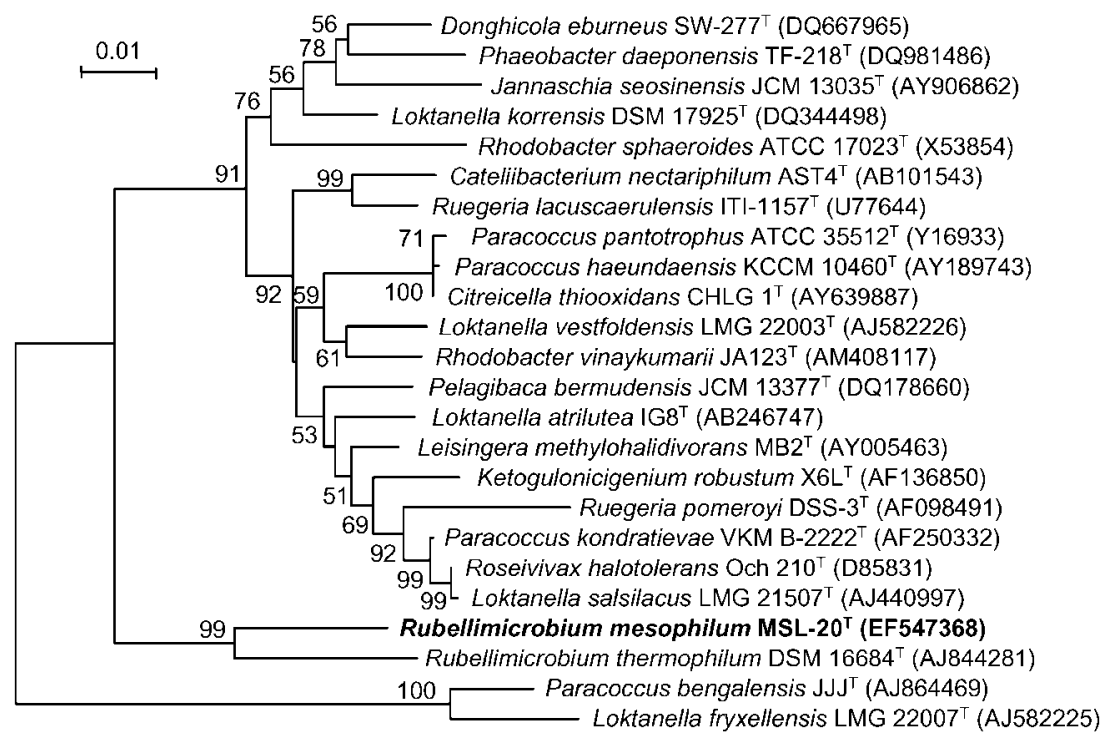

Fig. 2. Neighbour-joining phylogenetic tree based on 16S rRNA gene sequences showing the position of strain $\mathrm{MSL}-20^{\top}$ and some related taxa. Bootstrap values (expressed as percentages of 1000 replications) above $50 \%$ are shown at branch points. Bar, 0.01 substitutions per nucleotide position. 
Table 1. Characteristics that distinguish strain $M S L-20^{\top}$ and R. thermophilum DSM $16684^{\top}$

Data for R. thermophilum DSM $16684^{\mathrm{T}}$ were taken from Denner et al. (2006). Both strains are positive for utilization of D-fructose and negative for utilization of citrate and propionate.

\begin{tabular}{|c|c|c|}
\hline Characteristic & Strain MSL-20 ${ }^{\mathrm{T}}$ & $\begin{array}{l}\text { R. thermophilum } \\
\text { DSM } 16684^{\mathrm{T}}\end{array}$ \\
\hline $\begin{array}{l}\text { Optimum growth } \\
\text { temperature }\left({ }^{\circ} \mathrm{C}\right)\end{array}$ & 28 & $45-54$ \\
\hline \multicolumn{3}{|l|}{ Substrate utilization } \\
\hline L-Rhamnose & - & + \\
\hline L-Histidine & + & - \\
\hline L-Leucine & + & - \\
\hline \multicolumn{3}{|c|}{ Utilization of carbon compounds } \\
\hline Cellobiose & - & + \\
\hline D-Mannose & - & + \\
\hline Salicin & - & + \\
\hline D-Xylose & - & + \\
\hline$\alpha$-Melibiose & - & + \\
\hline D-Sorbitol & - & + \\
\hline L-Malate & - & + \\
\hline D-Ribose & - & + \\
\hline Major fatty acids & $\begin{array}{c}\mathrm{C}_{16: 0}, \mathrm{C}_{18: 1} \omega 7 c \\
\text { 11-methyl } \\
\mathrm{C}_{18: 1} \omega 7 c\end{array}$ & $\begin{array}{c}\mathrm{C}_{19: 0} \text { cyclo } \omega 8 c, \mathrm{C}_{18: 0}, \\
\mathrm{C}_{16: 0}\end{array}$ \\
\hline $\begin{array}{l}\text { DNA G }+\mathrm{C} \text { content } \\
(\mathrm{mol} \%)\end{array}$ & 72.3 & $69.4-70.2(70.0)^{*}$ \\
\hline Source of isolation & Soil & Paper mill \\
\hline
\end{tabular}

${ }^{*}$ Range of values for four strains. The DNA G $+C$ content of the type strain is given in parentheses.

Cells are Gram-negative, motile, non-flagellated, irregular rods, $0.4-0.7 \times 1.6-3.4 \mu \mathrm{m}$. Colonies on R2A medium are pink to light reddish. Oxidase and nitrate reduction activities are negative, whereas catalase activity is weakly positive. Positive for starch and Tween 80 hydrolysis and assimilation of cellulose, histidine, leucine and fructose. Tests for leucine arylamidase, naphthol-AS-BI-phosphohydrolase and $\alpha$-glucosidase are positive (API ZYM; bioMérieux). Growth is observed at $20-37{ }^{\circ} \mathrm{C}$ (optimum $28{ }^{\circ} \mathrm{C}$ ) and at $\mathrm{pH} 7-11$ (optimum pH 7.0 \pm 0.2 ); no growth in the presence of $\mathrm{NaCl}$. The major respiratory quinone is ubiquinone Q-10. The dominant fatty acids are $\mathrm{C}_{16: 0}(36.91 \%), \mathrm{C}_{18: 1} \omega 7 c(36.50 \%)$, 11-methyl $\mathrm{C}_{18: 1} \omega 7 c(12.40 \%), \mathrm{C}_{18: 0}(3.63 \%), \mathrm{C}_{10: 0}(1.27 \%)$, $\mathrm{C}_{12: 0}(1.26 \%)$ and $\mathrm{C}_{17: 0}(1.22 \%)$. The DNA G $+\mathrm{C}$ content of the type strain is $72.3 \mathrm{~mol} \%$.

The type strain, MSL- $20^{\mathrm{T}} \quad\left(=\mathrm{KCTC} 22012^{\mathrm{T}}=\mathrm{DSM}\right.$ $\left.19309^{\mathrm{T}}\right)$, was isolated from soil from Bigeum island, Republic of Korea.

\section{Acknowledgements}

This work was supported by the 21C Frontier Microbial Genomics and Application Centre program, Korean Ministry of Science \&
Technology (MOST), and the Korea Foundation for International Cooperation of Science \& Technology (KICOS) through a grant provided by MOST in the Global Partnership Program (no. M60602000001-06E0200-00100), Republic of Korea.

\section{References}

Altenburger, P., Kämpfer, P., Makristathis, A., Lubitz, W. \& Busse, H.-J. (1996). Classification of bacteria isolated from a medieval wall painting. J Biotechnol 47, 39-52.

Chun, J., Lee, J.-H., Jung, Y., Kim, M., Kim, S., Kim, B. K. \& Lim, Y. W. (2007). EzTaxon: a web-based tool for the identification of prokaryotes based on $16 \mathrm{~S}$ ribosomal RNA gene sequence. Int J Syst Evol Microbiol 57, 2259-2261.

Denner, E. B. M., Kolari, M., Hoornstra, D., Tsitko, I., Kämpfer, P., Busse, H.-J. \& Salkinoja-Salonen, M. (2006). Rubellimicrobium thermophilum gen. nov., sp. nov., a red-pigmented, moderately thermophilic bacterium isolated from coloured slime deposits in paper machines. Int J Syst Evol Microbiol 56, 13551362.

Felsenstein, J. (1985). Confidence limits on phylogenies: an approach using the bootstrap. Evolution 39, 783-791.

Felsenstein, J. (1993). PHYLIP (phylogeny inference package), version 3.5c. Distributed by the author. Department of Genome Sciences, University of Washington, Seattle, USA.

Garrity, G. M., Bell, J. A. \& Lilburn, T. (2005). Family I. Rhodobacteraceae fam. nov. In Bergey's Manual of Systematic Bacteriology, 2nd edn, vol. 2, The Proteobacteria, part C, The Alpha-, Beta-, Delta-, and Epsilonproteobacteria, p. 161. Edited by D. J. Brenner, N. R. Krieg, J. T. Staley \& G. M. Garrity. New York: Springer.

Goodfellow, M. (1971). Numerical taxonomy of some nocardioform bacteria. J Gen Microbiol 69, 33-80.

Kämpfer, P. \& Kroppenstedt, R. M. (1996). Numerical analysis of fatty acid patterns of coryneform bacteria and related taxa. Can J Microbiol 42, 989-1005.

Kimura, M. (1980). A simple method for estimating evolutionary rates of base substitutions through comparative studies of nucleotide sequences. J Mol Evol 16, 111-120.

Kimura, M. (1983). The Neutral Theory of Molecular Evolution. Cambridge: Cambridge University Press.

Kumar, S., Tamura, K., Jakobsen, I.-B. \& Nei, M. (2001). MEGA2: molecular evolutionary genetics analysis software. Bioinformatics $\mathbf{1 7}$, 1244-1245.

Lechevalier, M. P., Stern, A. E. \& Lechevalier, H. A. (1981). Phospholipids in the taxonomy of actinomycetes. Zentralbl Bakteriol Hyg Abt I (Suppl. 11), 111-116.

Rainey, F. A., Ward-Rainey, N., Kroppenstedt, R. M. \& Stackebrandt, E. (1996). The genus Nocardiopsis represents a phylogenetically coherent taxon and distinct actinomycetes lineage: proposal of Nocardiopsaceae fam. nov. Int J Syst Bacteriol 46, 1088-1092.

Saitou, N. \& Nei, M. (1987). The neighbor-joining method: a new method for reconstructing phylogenetic trees. Mol Biol Evol 4, 406425.

Sasser, M. (1990). Identification of bacteria by gas chromatography of cellular fatty acids. USFCC Newsl 20, 16.

Shirling, E. B. \& Gottlieb, D. (1966). Methods for characterization of Streptomyces species. Int J Syst Bacteriol 16, 313-340.

Thompson, J. D., Gibson, T. J., Plewniak, F., Jeanmougin, F. \& Higgins, D. G. (1997). The CLUSTAL_X windows interface: flexible 
strategies for multiple sequence alignment aided by quality analysis tools. Nucleic Acids Res 25, 4876-4882.

Tsukamura, M. (1966). Adansonian classification of mycobacteria. J Gen Microbiol 45, 253-273.
Williams, S. T., Goodfellow, M., Alderson, G., Wellington, E. M. H., Sneath, P. H. A. \& Sackin, M. J. (1983). Numerical classification of Streptomyces and related genera. J Gen Microbiol 129, 1743-1813. 